\title{
Pseudomonas caeni sp. nov., a denitrifying bacterium isolated from the sludge of an anaerobic ammonium-oxidizing bioreactor
}

\author{
Yi-Ping Xiao, ${ }^{1}$ Wei Hui, ${ }^{1}$ Qiang Wang, ${ }^{1}$ Seong Woon Roh, ${ }^{2}$ Xue-Qing Shi, ${ }^{1}$ \\ Jin-Huan Shi ${ }^{1}$ and Zhe-Xue Quan ${ }^{1}$ \\ ${ }^{1}$ Department of Microbiology and Microbial Engineering, School of Life Sciences, Fudan University, \\ Shanghai 200433, PR China \\ ${ }^{2}$ Biological Resource Center, Korea Research Institute of Bioscience and Biotechnology, Daejeon \\ 305-333, Republic of Korea
}

Correspondence

Zhe-Xue Quan

quanzx@fudan.edu.cn

\begin{abstract}
Two Gram-negative, rod-shaped, motile, aerobic bacterial strains designated $\mathrm{HY}-14^{\top}$ and $\mathrm{HY}-24$ were isolated from the sludge of an anaerobic ammonium-oxidizing bioreactor. The strains could not grow with $5 \%(w / v) ~ N a C l$, did not produce acid from D-glucose or utilize D-glucose, gluconate or citrate as a sole carbon source. Summed feature 3 and $\mathrm{C}_{16: 0}$ were the most abundant fatty acids; hydroxyl fatty acids $\mathrm{C}_{12: 0} 3-\mathrm{OH}$ and $\mathrm{C}_{10: 0} 3-\mathrm{OH}$ were also present. Fatty acid $\mathrm{C}_{12: 0}$ 2-OH was absent. The DNA G $+\mathrm{C}$ contents of strains $\mathrm{HY}-14^{\top}$ and $\mathrm{HY}-24$ were $50.6 \pm 0.5 \mathrm{~mol} \%$. Phylogenetic analyses based on 16S rRNA gene sequences showed that strains $\mathrm{HY}-14^{\top}$ and HY-24 formed a monophyletic clade within the genus Pseudomonas. The highest sequence similarities were to Pseudomonas pseudoalcaligenes DSM $50188^{\top}$ (95.9\%). On the basis of phenotypic and phylogenetic properties, strains $\mathrm{HY}-14^{\top}$ and $\mathrm{HY}-24$ are proposed as a novel species of the genus Pseudomonas, for which the name Pseudomonas caeni sp. nov. is proposed. The type strain is HY $-14^{\top}\left(=\right.$ KCTC $22292^{\top}=$ CCTCC AB208156 ${ }^{\top}$ ).
\end{abstract}

The genus Pseudomonas was first proposed by Migula (1894). Members of the genus Pseudomonas are widely distributed in a variety of environments such as soil, water, wastewater plants and clinical specimens.

Strain HY $-14^{\mathrm{T}}$ was isolated from the sludge of an anaerobic ammonium-oxidizing (Anammox) bioreactor by the dilution-plating technique on R2A (Difco) agar plates under aerobic conditions. Strain HY-24 was isolated from the sludge of the Anammox bioreactor on modified R2A (containing $5 \mathrm{mM} \mathrm{NaNO}_{3}$ and $0.1 \mathrm{mM} \mathrm{Na}_{2} \mathrm{~S}$ ) agar plates in an anaerobic test tube using an AnaeroGen kit (Oxoid). Cell morphology was examined by light microscopy (YS-2; Nikon) and transmission electron microscopy (H600; Hitachi) after negative staining with $1 \%(\mathrm{w} / \mathrm{v})$ phosphotungstic acid, using cells grown on tryptic soy agar (TSA, Difco) after 2 days incubation at $30{ }^{\circ} \mathrm{C}$. Motility was determined by phase-contrast microscopy (Eclipse TS 100; Nikon). Growth in the presence of $0,0.5,1,2,3$ and $5 \%$ $(\mathrm{w} / \mathrm{v}) \mathrm{NaCl}$ and at $\mathrm{pH} 5.0-11.0$ (in increments of $1 \mathrm{pH}$

The GenBank/EMBL/DDBJ accession numbers for the 16S rRNA gene sequences of strains HY-14 ${ }^{\top}$ and HY-24 are EU620679 and EU620680, respectively.

A transmission electron micrograph of a negatively stained cell of strain $\mathrm{HY}-14^{\top}$, showing a polar flagellum, is available with the online version of this paper. unit) and at $4,10,20,30,37$ and $42{ }^{\circ} \mathrm{C}$ was tested on TSA for up to 1 week. The production of water-soluble fluorescent pigments on King's B agar was determined as described by King et al. (1954). Catalase activity was determined by bubble production in $3 \%(\mathrm{v} / \mathrm{v})$ hydrogen peroxide solution; oxidase activity was determined by oxidation of $1 \%(\mathrm{w} / \mathrm{v})$ tetramethyl $p$-phenylenediamine (Merck). Gram staining, hydrolysis of starch, gelatin and Tween 80, endospore formation and utilization of arabinose and malate as the sole carbon resource were determined as described by Dong \& Cai (2001). The denitrification rate was measured as nitrite consumed over time under anaerobic conditions, according to the methods described by Gumaelius et al. (1996, 2001). Other physiological and biochemical tests and enzyme activities were conducted using API 20NE and API ZYM strips (bioMérieux) according to the manufacturer's instructions. Pseudomonas aeruginosa KCTC $1750^{\mathrm{T}}$, Pseudomonas chlororaphis DSM 50083 ${ }^{\mathrm{T}}$, Pseudomonas fluorescens KCTC $12453^{\mathrm{T}}$, Pseudomonas mendocina DSM 50017 ${ }^{\mathrm{T}}$, Pseudomonas pseudoalcaligenes KACC $10304^{\mathrm{T}}$, Pseudomonas putida KCTC $1751^{\mathrm{T}}$ and Pseudomonas stutzeri KCTC $1066^{\mathrm{T}}$ were included in these studies and analysed under the same conditions.

Strains $\mathrm{HY}-14^{\mathrm{T}}$ and $\mathrm{HY}-24$ had the same cultural, physiological and biochemical characteristics. The two 
novel strains grew faster on R2A agar under aerobic conditions than on modified R2A agar under anaerobic conditions and had essentially the same denitrification rate $\left[2.2 \pm 0.2 \mathrm{mg} \mathrm{NO}_{2}^{-}-\mathrm{N} \mathrm{h}^{-1}\right.$ (g wet cells) $\left.{ }^{-1}\right]$ under anaerobic conditions. Additional cultural, physiological and biochemical characteristics of strains HY-14 ${ }^{\mathrm{T}}$ and HY-24 are given in the species description and in Table 1. The two novel strains could be readily differentiated from other pseudomonads on the basis of several phenotypic properties such as no growth with $5 \% \mathrm{NaCl}$, the acidification of glucose and the utilization of D-glucose, gluconate and citrate as the sole carbon source.

For quantitative analysis of the cellular fatty acid composition, $40 \mathrm{mg}$ wet cell material was harvested from TSA plates after 2 days incubation at $28{ }^{\circ} \mathrm{C}$. The cellular fatty acids were extracted, saponified and methylated according to the protocol of the Sherlock Microbial Identification System (MIDI). The fatty acids were analysed by GC (Hewlett Packard 6890) and identified by the Microbial Identification software package (Sasser, 1990). Chromosomal DNA was isolated and purified using a Cell Culture DNA Midi kit (Qiagen) according to the manufacturer's protocol. The $\mathrm{G}+\mathrm{C}$ content of the DNA was determined by the fluorescence monitoring method (Xu et al., 2000; Gonzalez \& Saiz-Jimenez, 2002) with a real-time thermal cycler (Mx3000p; Stratagene). The genomic DNA of Escherichia coli strain B (Sigma-Aldrich) and $P$. aeruginosa KCTC $1750^{\mathrm{T}}$ were used as the calibration references. The tests were repeated five times.

The cellular fatty acid profiles of strains HY- $14^{\mathrm{T}}$ and HY-24 and related species are presented in Table 2. Strains HY- $14^{\mathrm{T}}$ and HY-24 contained high amounts of summed feature 3 (37.4-37.6\%; comprising $\mathrm{C}_{16: 1} \omega 7 c$ and/or iso- $\mathrm{C}_{15: 0}$ $2-\mathrm{OH}), \mathrm{C}_{16: 0}(28.1-28.3 \%)$ and $\mathrm{C}_{18: 1} \omega 7 c(13.4-13.7 \%)$, with lesser amounts of $\mathrm{C}_{12: 0}(7.9-8.1 \%), \mathrm{C}_{10: 0} 3-\mathrm{OH}$ (4.3$4.4 \%), \mathrm{C}_{12: 0} 3-\mathrm{OH}(3.1-3.3 \%)$ and $\mathrm{C}_{14: 0}(1.4-1.6 \%)$. The

Table 1. Differential characteristics of strains $\mathrm{HY}-14^{\top}$ and $\mathrm{HY}-24$ and related species of the genus Pseudomonas

Taxa: 1, strains HY-14 ${ }^{\mathrm{T}}$ and HY-24; 2, P. pseudoalcaligenes KACC $10304^{\mathrm{T}} ; 3$, P. stutzeri KCTC $1066^{\mathrm{T}} ; 4$, P. mendocina DSM 50017 ${ }^{\mathrm{T}}$; 5, P. aeruginosa KCTC $1750^{\mathrm{T}}$; 6, P. chlororaphis DSM $50083^{\mathrm{T}}$; 7, P. fluorescens KCTC $12453^{\mathrm{T}}$; 8, P. putida KCTC $1751^{\mathrm{T}}$. Data are from this study. All strains are positive for catalase and oxidase activities, motility and utilization of caprate as sole carbon source. All strains are negative for the following characteristics: urease, $\beta$-galactosidase and $\beta$-glucosidase activities, indole production and utilization of phenylacetate as sole carbon source. + , Positive; -, negative.

\begin{tabular}{|c|c|c|c|c|c|c|c|c|}
\hline Characteristic & 1 & 2 & 3 & 4 & 5 & 6 & 7 & 8 \\
\hline Fluorescent pigments & - & - & - & - & + & + & + & + \\
\hline Arginine dihydrolase & - & - & - & + & + & + & + & + \\
\hline Growth with $5 \% \mathrm{NaCl}$ & - & + & + & + & + & + & + & + \\
\hline \multicolumn{9}{|l|}{ Growth at: } \\
\hline $4{ }^{\circ} \mathrm{C}$ & + & - & - & - & - & + & + & + \\
\hline \multicolumn{9}{|l|}{ Hydrolysis of: } \\
\hline Gelatin & - & - & - & - & + & + & + & - \\
\hline Starch & - & - & + & - & - & - & - & - \\
\hline Tween 80 & - & - & + & + & + & + & + & - \\
\hline Denitrification & + & - & + & + & + & + & - & - \\
\hline \multicolumn{9}{|l|}{ Acid produced from: } \\
\hline Arabinose & - & - & - & - & $+\left(--^{*}\right)$ & $+\left(-^{\star}\right)$ & - & - \\
\hline Citrate & - & - & + & + & + & + & + & + \\
\hline Gluconate & - & - & + & + & + & + & + & + \\
\hline D-Glucose & - & - & + & + & + & + & + & + \\
\hline Malate & + & + & + & + & + & + & $-\left(+^{*}\right)$ & + \\
\hline Maltose & - & - & + & - & - & - & - & - \\
\hline D-Mannitol & - & - & - & - & + & + & + & - \\
\hline Mannose & - & - & - & - & - & + & + & - \\
\hline DNA G $+C$ content $(\mathrm{mol} \%)$ & $50.1-51.1$ & $61.9-63.7$ & $62.5-64.3$ & $62.3-63.5$ & $66.6 \dagger$ & $62.5-63.9$ & $59.5-61.1$ & $61.5-62.3$ \\
\hline
\end{tabular}

${ }^{*}$ Data from API 20NE tests.

$\dagger$ Data from Gonzalez \& Saiz-Jimenez (2002). 
Table 2. Fatty acid content (\%) of strains $\mathrm{HY}-14^{\top}$ and $\mathrm{HY}-24$ and related species in the genus Pseudomonas

Taxa: 1, strain HY-14 $4^{\mathrm{T}}$; 2, strain HY-24; 3, P. pseudoalcaligenes KACC $10304^{\mathrm{T}}$; 4, P. stutzeri KCTC $1066^{\mathrm{T}}$; 5, P. mendocina DSM 50017 ${ }^{\mathrm{T}}$; 6, P. aeruginosa KCTC $1750^{\mathrm{T}}$; 7, P. chlororaphis DSM 50083 ${ }^{\mathrm{T}}$; 8, P. fluorescens KCTC $12453^{\mathrm{T}}$; 9, P. putida KCTC $1751^{\mathrm{T}}$. Data are from this study. ND, Not detected; tr, trace $(<1 \%)$. The fatty acids amounting to $<1 \%$ in all strains studied are not listed.

\begin{tabular}{|c|c|c|c|c|c|c|c|c|c|}
\hline Fatty acid & 1 & 2 & 3 & 4 & 5 & 6 & 7 & 8 & 9 \\
\hline \multicolumn{10}{|c|}{ Straight-chain saturated } \\
\hline $\mathrm{C}_{10: 0}$ & $\operatorname{tr}$ & $\operatorname{tr}$ & $\operatorname{tr}$ & $\operatorname{tr}$ & $\operatorname{tr}$ & $\operatorname{tr}$ & $\operatorname{tr}$ & $\operatorname{tr}$ & $\operatorname{tr}$ \\
\hline $\mathrm{C}_{10: 0} 3-\mathrm{OH}$ & 4.3 & 4.4 & 4.6 & 3.9 & 4.6 & 3.6 & 4.7 & 5.4 & 3.3 \\
\hline $\mathrm{C}_{12: 0}$ & 8.1 & 7.9 & 6.9 & 8.7 & 8.0 & 4.8 & 2.3 & 5.2 & 2.9 \\
\hline $\mathrm{C}_{12: 0} 2-\mathrm{OH}$ & ND & ND & ND & $\operatorname{tr}$ & $\operatorname{tr}$ & 3.7 & 4.9 & 5.4 & 4.1 \\
\hline $\mathrm{C}_{12: 0} 3-\mathrm{OH}$ & 3.1 & 3.3 & 3.3 & 4.0 & 4.3 & 4.5 & 4.6 & 6.1 & 3.7 \\
\hline $\mathrm{C}_{14: 0}$ & 1.6 & 1.4 & $\mathrm{ND}$ & 1.7 & 1.0 & 1.3 & 1.3 & 1.0 & 1.1 \\
\hline $\mathrm{C}_{15: 0}$ & $\operatorname{tr}$ & $\operatorname{tr}$ & 2.5 & $\mathrm{ND}$ & 1.6 & $\operatorname{tr}$ & $\operatorname{tr}$ & $\operatorname{tr}$ & $\operatorname{tr}$ \\
\hline $\mathrm{C}_{16: 0}$ & 28.1 & 28.3 & 11.2 & 16.3 & 12.7 & 20.5 & 26.7 & 19.1 & 27.2 \\
\hline $\mathrm{C}_{17: 0}$ & $\operatorname{tr}$ & $\mathrm{ND}$ & 2.3 & $\mathrm{ND}$ & $\operatorname{tr}$ & $\operatorname{tr}$ & $\operatorname{tr}$ & $\operatorname{tr}$ & $\operatorname{tr}$ \\
\hline $\mathrm{C}_{18: 0}$ & $\operatorname{tr}$ & $\operatorname{tr}$ & 1.4 & $\operatorname{tr}$ & $\operatorname{tr}$ & $\operatorname{tr}$ & $\operatorname{tr}$ & $\operatorname{tr}$ & $\operatorname{tr}$ \\
\hline \multicolumn{10}{|l|}{ Branched saturated } \\
\hline iso- $\mathrm{C}_{16: 0}$ & $\operatorname{tr}$ & $\operatorname{tr}$ & $\mathrm{ND}$ & ND & ND & $\operatorname{tr}$ & ND & ND & ND \\
\hline iso- $\mathrm{C}_{17: 0}$ & $\mathrm{ND}$ & ND & 1.5 & $\operatorname{tr}$ & $\operatorname{tr}$ & $\operatorname{tr}$ & ND & ND & ND \\
\hline $\mathrm{C}_{17: 0}$ cyclo & $\mathrm{ND}$ & $\mathrm{ND}$ & ND & $\operatorname{tr}$ & 4.3 & $\operatorname{tr}$ & 5.5 & 2.9 & 1.6 \\
\hline Summed feature $3^{\star}$ & 37.4 & 37.6 & 15.0 & 31.5 & 23.2 & 20.0 & 34.5 & 38.5 & 30.5 \\
\hline \multicolumn{10}{|l|}{ Mono-unsaturated } \\
\hline $\mathrm{C}_{17: 1} \omega 5 c$ & ND & ND & 4.1 & ND & ND & ND & ND & ND & ND \\
\hline $\mathrm{C}_{17: 1} \omega 6 c$ & ND & $\mathrm{ND}$ & 2.3 & $\mathrm{ND}$ & $\mathrm{ND}$ & ND & ND & $\mathrm{ND}$ & ND \\
\hline $\mathrm{C}_{17: 1} \omega 8 c$ & $\mathrm{ND}$ & ND & 3.0 & ND & 2.1 & $\operatorname{tr}$ & $\operatorname{tr}$ & $\operatorname{tr}$ & ND \\
\hline $\mathrm{C}_{18: 1} \omega 7 c$ & 13.7 & 13.4 & 38.3 & 31.5 & 34.0 & 38.9 & 13.8 & 14.9 & 22.3 \\
\hline
\end{tabular}

${ }^{*}$ Summed feature 3 comprised $\mathrm{C}_{16: 1} \omega 7 c$ and/or iso- $\mathrm{C}_{15: 0} 2-\mathrm{OH}$.

two novel strains had similar fatty acid profiles to $P$. chlororaphis DSM $50083^{\mathrm{T}}$, P. fluorescens KCTC $12453^{\mathrm{T}}$ and P. putida KCTC $1751^{\mathrm{T}}$, containing high amounts of summed feature 3 and $\mathrm{C}_{16: 0}$. The novel strains also had the typical hydroxyl fatty acids $\mathrm{C}_{12: 0} 3-\mathrm{OH}$ and $\mathrm{C}_{10: 0}$ $3-\mathrm{OH}$ but did not contain fatty acid $\mathrm{C}_{12: 0} 2-\mathrm{OH}$. The fatty acid profiles suggested that strains $\mathrm{HY}-14^{\mathrm{T}}$ and $\mathrm{HY}-24$ belonged to the genus Pseudomonas (Oyaizu \& Komagata, 1983). The DNA G $+\mathrm{C}$ contents of the two strains (with five replications) were $50.6 \pm 0.5 \mathrm{~mol} \%$. This level of $\mathrm{G}+\mathrm{C}$ was greatly below the range (58-69 mol\%) previously described for members of the genus Pseudomonas (Palleroni, 2005), however, Pseudomonas duriflava $\mathrm{HR}^{\mathrm{T}}$, a recently described species, has also been reported to have a low DNA G+C content (55.2 mol\%) (Liu et al., 2008). The DNA G $+\mathrm{C}$ contents of $P$. aeruginosa $\mathrm{KCTC} 1750^{\mathrm{T}}, P$. chlororaphis DSM 50083 ${ }^{\mathrm{T}}$, P. fluorescens KCTC $12453^{\mathrm{T}}, P$. mendocina DSM 50017 ${ }^{\mathrm{T}}, P$. pseudoalcaligenes KACC $10304^{\mathrm{T}}, P$. stutzeri KCTC $1066^{\mathrm{T}}$ and P. putida KCTC $1751^{\mathrm{T}}$ were also determined by the fluorescence monitoring method in this study and the results were consistent with those given in the literature (Palleroni, 2005) (Table 1).

The 16S rRNA genes of strains HY $-14^{\mathrm{T}}$ and HY-24 were amplified by PCR using the universal primer pair $9 \mathrm{~F}$ and $1512 \mathrm{R}$ as described previously (Quan et al., 2005). The
PCR products were purified with a QIAquick PCR Purification kit (Qiagen) and sequenced using an Applied Biosystems 3730X1 DNA Analyzer and the primers 519F, 536R, 907F, 1100R (Quan et al., 2005). The typical 16S rRNA gene sequences of related taxa were obtained from EzTaxon (Chun et al., 2007) and multiple alignments were performed using the CLUSTAL_X program (Thompson et al., 1997). Gaps at the $5^{\prime}$ and $3^{\prime}$ ends of the alignment were omitted from further analysis. Phylogenetic trees were constructed based on the neighbour-joining (Saitou \& Nei, 1987) and maximum-parsimony (Swofford, 1993) algorithms using the MEGA4 program (Tamura et al., 2007) with bootstrap values based on 1000 replications (Felsenstein, 1985). The evolutionary distances were calculated using the method of Jukes \& Cantor (1969).

The nearly complete $16 \mathrm{~S}$ rRNA gene sequences of strains HY $-14^{\mathrm{T}}$ and HY-24 (1508 bp) were obtained. Strain HY-24 showed $99.9 \% 16 \mathrm{~S}$ rRNA gene sequence similarity to strain HY- $14^{\mathrm{T}}$. Phylogenetic trees based on the neighbour-joining and maximum-parsimony methods indicated that the novel strains formed a monophyletic clade within the genus Pseudomonas (Fig. 1) with the genus Cellvibrio of the family Pseudomonadaceae used as the outgroup. On the basis of $16 \mathrm{~S}$ rRNA gene similarity, the closest relative was $P$. pseudoalcaligenes DSM $50188^{\mathrm{T}}$ (95.9\%), suggesting that the 


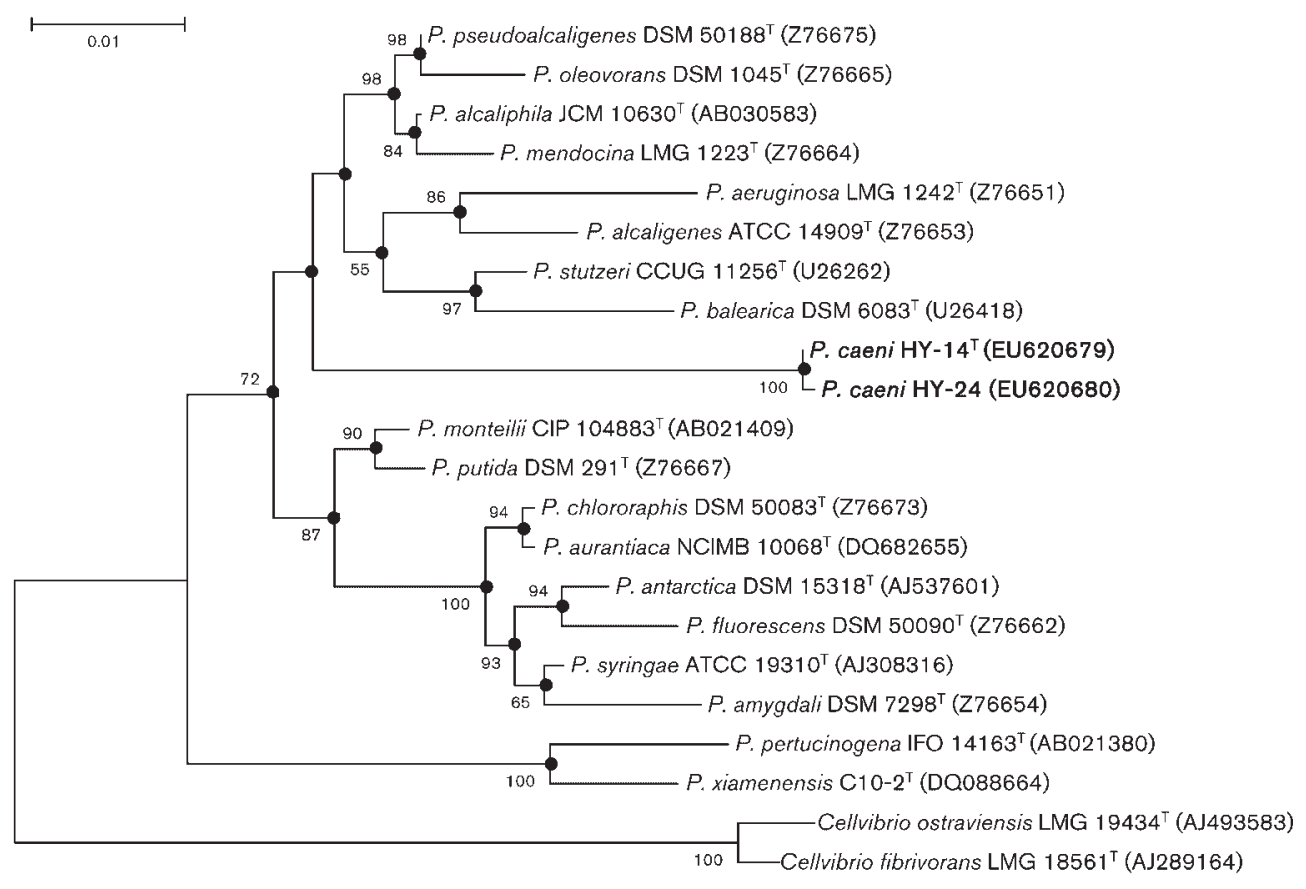

Fig. 1. Neighbour-joining phylogenetic tree based on $16 \mathrm{~S}$ rRNA gene sequences (1325 bp) showing the relationship of Pseudomonas caeni sp. nov. strains $\mathrm{HY}-14^{\top}$ and $\mathrm{HY}-24$ and related species in genus Pseudomonas. Cellvibrio ostraviensis LMG $19434^{\top}$ and Cellvibrio fibrivorans LMG $18561^{\top}$ were used as the outgroup. Filled circles indicate branches that were also recovered by using the maximum-parsimony algorithm. Bootstrap values (expressed as percentages of 1000 replications) greater than 50 are shown at the branching points. Bar, 1 substitution per 100 nucleotide positions.

new strains represent a novel genomic species, without the need for DNA-DNA hybridization characterization (Stackebrandt \& Goebel, 1994).

On the basis of the phylogenetic tree and fatty acid profiles, it is proposed that strains HY-14 and HY-24 belong to the genus Pseudomonas. Due to the large phylogenetic distance and different phenotypic characteristics of the new strains when compared with those of the type strains of members of the genus Pseudomonas, strains HY-14 ${ }^{\mathrm{T}}$ and HY-24 should be classified as a novel species of the genus Pseudomonas, for which the name Pseudomonas caeni sp. nov. is proposed.

\section{Description of Pseudomonas caeni sp. nov.}

Pseudomonas caeni (cae' ni. L. gen. neut. n. caeni of sludge).

Cells are Gram-negative, aerobic, non-spore-forming rods approximately $0.4-0.7 \times 1.0-2.0 \mu \mathrm{m}$ in size. Cells are motile by means of a polar flagellum (see Supplementary Fig. S1 in IJSEM Online). Colonies on TSA are translucent, pale yellow, circular and usually $1-2 \mathrm{~mm}$ in diameter after 2 days incubation at $30{ }^{\circ} \mathrm{C}$. Cells do not produce fluorescent pigment on King's B media. Growth occurs at $4-37{ }^{\circ} \mathrm{C}$ (optimum, $30{ }^{\circ} \mathrm{C}$ ), but not at $42{ }^{\circ} \mathrm{C}$. Growth occurs at $\mathrm{pH}$ 6.0-10.0 (optimum, $\mathrm{pH}$ 7.0-8.0). Growth occurs in the presence of $0-3 \%(\mathrm{w} / \mathrm{v}) \mathrm{NaCl}$ (optimum, $0.5-1 \%)$, but not in the presence of $5 \%(\mathrm{w} / \mathrm{v}) \mathrm{NaCl}$. Catalase- and oxidase-positive. Positive for esterase (C4), esterase lipase (C8) and leucine arylamidase, but negative for activities of urease, $\alpha$-glucosidase, $\beta$-glucosidase, lipase (C14), arginine dihydrolase, $\alpha$-chymotrypsin, $\alpha$-galactosidase, $\beta$-galactosidase, naphthol-AS-BI-phosphohydrolase, alkaline phosphatase, acid phosphatase, valine arylamidase, cystine arylamidase, $\beta$-glucuronidase, $\alpha$-fucosidase, $\alpha$ mannosidase and $N$-acetyl- $\beta$-glucosaminidase. Negative for acidification of D-glucose, indole production and hydrolysis of starch, aesculin, gelatin, trypsin and Tween 80. Nitrate and nitrite are reduced under anaerobic conditions. Caprate and malate are utilized as sole carbon sources, but the following substrates are not utilized as a sole carbon source: adipate, arabinose, citrate, D-glucose, gluconate, maltose, mannitol, mannose, $\mathrm{N}$-acetylglucosamine or phenylacetate. The major fatty acids are summed feature $3, \mathrm{C}_{16: 0}$ and $\mathrm{C}_{18: 1} \omega 7 \mathrm{c}$, with smaller amounts of $\mathrm{C}_{12: 0}, \mathrm{C}_{10: 0} 3-\mathrm{OH}, \mathrm{C}_{12: 0} 3-\mathrm{OH}$ and $\mathrm{C}_{14: 0}$. The $\mathrm{G}+\mathrm{C}$ content of the genomic DNA is $50.6 \pm 0.5 \mathrm{~mol} \%$.

The type strain, HY- $14^{\mathrm{T}} \quad\left(=\mathrm{KCTC} 22292^{\mathrm{T}}=\mathrm{CCTCC}\right.$ $\left.\mathrm{AB} 208156^{\mathrm{T}}\right)$ and an additional strain, HY-24 (=KCTC $22293=$ CCTCC AB208157), were isolated from the sludge of an anaerobic ammonium-oxidizing bioreactor.

\section{Acknowledgements}

This work was supported by the National Natural Science Foundation of China (No. 30600012). 


\section{References}

Chun, J., Lee, J. H., Jung, Y. Y., Kim, M. J., Kim, S., Kim, B. K. \& Lim, Y. W. (2007). EzTaxon: a web-based tool for the identification of prokaryotes based on 16S ribosomal RNA gene sequences. Int J Syst Evol Microbiol 57, 2259-2261.

Dong, X.-Z. \& Cai, M.-Y. (2001). Determinative Manual for Routine Bacteriology. Beijing: Scientific Press.

Felsenstein, J. (1985). Confidence limits on phylogenies: an approach using the bootstrap. Evolution 39, 783-791.

Gonzalez, J. M. \& Saiz-Jimenez, C. (2002). A fluorimetric method for the estimation of $\mathrm{G}+\mathrm{C}$ mol\% content in microorganisms by thermal denaturation temperature. Environ Microbiol 4, 770-773.

Gumaelius, L., Smith, E. H. \& Dalhammar, G. (1996). Potential biomarker for denitrification of wastewaters: effects of process variables and cadmium toxicity. Water Res 30, 3025-3031.

Gumaelius, L., Magnusson, G., Pettersson, B. \& Dalhammar, G. (2001). Comamonas denitrificans sp. nov., an efficient denitrifying bacterium isolated from activated sludge. Int J Syst Evol Microbiol 51, 999-1006.

Jukes, T. H. \& Cantor, C. R. (1969). Evolution of protein molecules. In Mammalian Protein Metabolism, vol. 3, pp. 21-132. Edited by H. N. Munro. New York: Academic Press.

King, E. O., Ward, M. K. \& Raney, D. E. (1954). Two simple media for the demonstration of pyocyanin and fluorescein. J Lab Clin Med 44, 301-307.

Liu, R., Liu, H., Feng, H., Wang, X., Zhang, C.-X., Zhang, K.-Y. \& Lai, R. (2008). Pseudomonas duriflava sp. nov., isolated from a desert soil. Int J Syst Evol Microbiol 58, 1404-1408.

Migula, W. (1894). Über ein neues System der Bakterien. Arb Bakteriol Inst Technisch Hochsch Karlsruhe 1, 235-238 (in German).

Oyaizu, H. \& Komagata, K. (1983). Grouping of Pseudomonas species on the basis of cellular fatty acid composition and the quinone system with special reference to the existence of 3-hydroxy fatty acids. J Gen Appl Microbiol 29, 17-40.

Palleroni, N. J. (2005). Genus I. Pseudomonas. In Bergey's Manual of Systematic Bacteriology, 2nd edn, vol. 2, pp. 323-379. Edited by D. J. Brenner, N. R. Krieg, J. T. Staley \& G. M. Garrity. East Lansing: Springer.

Quan, Z. X., Bae, H. S., Baek, J. H., Chen, W. F., Im, W. T. \& Lee, S. T. (2005). Rhizobium daejeonense sp. nov. isolated from a cyanide treatment bioreactor. Int J Syst Evol Microbiol 55, 2543-2549.

Saitou, N. \& Nei, M. (1987). The neighbour-joining method: a new method for reconstructing phylogenetic trees. Mol Biol Evol 4, 406-425.

Sasser, M. (1990). Identification of bacteria by gas chromatography of cellular fatty acids, MIDI Technical Note 101. Newark, DE: MIDI Inc.

Stackebrandt, E. \& Goebel, B. M. (1994). Taxonomic note: a place for DNA-DNA reassociation and $16 \mathrm{~S}$ rRNA sequence analysis in the present species definition in bacteriology. Int J Syst Bacteriol 44, 846-849.

Swofford, D. L. (1993). PAUP. Phylogenetic Analysis Using Parsimony, version 3.1.1. Champaign, IL: Illinois Natural History Survey.

Tamura, K., Dudley, J., Nei, M. \& Kumar, S. (2007). MEGA4: molecular evolutionary genetics analysis (MEGA) software version 4.0. Mol Biol Evol 24, 1596-1599.

Thompson, J. D., Gibson, T. J., Plewniak, F., Jeanmougin, F. \& Higgins, D. G. (1997). The CLUSTAL_X windows interface: flexible strategies for multiple sequence alignment aided by quality analysis tools. Nucleic Acids Res 25, 4876-4882.

Xu, H.-X., Kawamura, Y., Li, N., Zhao, L., Li, T.-M., Li, Z.-Y., Shu, S. \& Ezaki, T. (2000). A rapid method for determining the $\mathrm{G}+\mathrm{C}$ content of bacterial chromosomes by monitoring fluorescence intensity during DNA denaturation in a capillary tube. Int $J$ Syst Evol Microbiol 50, 1463-1469. 